THE TEXAS LAND AND DEVELOPMENT COMPANY 
THIS PAGE INTENTIONALLY LEFT BLANK 
NUMBeR 9 The M. K. Brown Range Life Series 
THIS PAGE INTENTIONALLY LEFT BLANK 


\section{THE TEXAS LAND AND DEVELOPMENT COMPANY}

A Panhandle Promotion, 1912-1956

by B. R. BRUNSON

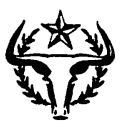

UNIVERSITY OF TEXAS PRESS, AUSTIN AND LONDON 
International Standard Book Number 0-292-70038-5 Library of Congress Catalog Card Number 70-117722

(C) 1970 by B. R. Brunson All Rights Reserved Manufactured in the United States of America 
TO M Y MOTHER

Lura Hazel Early Brunson 
THIS PAGE INTENTIONALLY LEFT BLANK 